\title{
INTERNATIONAL MASTER DEGREE PARTNERSHIP THROUGH DOUBLE DIPLOMA PROGRAMME OF INTERNATIONAL FINANCIAL MANAGEMENT (ON THE EXAMPLE OF BULGARIA AND UKRAINE)
}

\author{
Andrey Zahariev ${ }^{1 *}$, Oleksandra Laktionova ${ }^{2}$, Galina Zaharieva ${ }^{3}$ and Dimitar Kostov ${ }^{4}$ \\ ${ }^{1}$ Prof. Dr., D. A. Tsenov Academy of Economics, Svishtov, Bulgaria, \\ andrey.zahariev.1971@gmail.com \\ ${ }^{2}$ Prof. Dr., Vasyl Stus Donetsk National University, Vinnytsia, Ukraine, \\ laktionova.loa@donnu.edu.ua \\ ${ }^{3}$ Assoc. Prof. Dr., D. A. Tsenov Academy of Economics, Svishtov, Bulgaria, g.zaharieva@uni- \\ svishtov.bg \\ ${ }^{4}$ Head Assist. Prof. Dr., D. A. Tsenov Academy of Economics, Svishtov, Bulgaria, d.kostov@uni- \\ svishtov.bg \\ ${ }^{*}$ Corresponding author
}

\begin{abstract}
The Bulgarian-Ukrainian master's degree program for double degree between D. A. Tsenov Academy of Economics, Svishtov, Bulgaria and Vasyl Stus Donetsk National University, Vinnytsia, Ukraine was approved in 2017. In the academic year 2017/2018 the first alumni of Ukrainian students was accepted, and in the academic year 2019/2020, respectively the second class of Ukrainian students was admitted. The curriculum includes three semesters of full-time study, of which the first and third are provided by the Ukrainian partner, and the second semester - by the Bulgarian side. Each semester includes compulsory or elective courses, which lead to the accumulation of 30 ECTS credits. The training is in the field of social sciences, professional field "Economics", specialty "Finance" in the master's program "International Financial Management". Teaching and learning documentation is in English only. On the Bulgarian side, all training courses are provided with textbooks prepared by members of the Department of Finance and Banking, which are available in electronic and paper format. Each Ukrainian student is provided with a free set of textbooks by the Bulgarian partner. The first two semesters of the training are in academic disciplines, ending with an exam. In the third semester there is an undergraduate internship, scientific guidance and review of the thesis. The end of the training is a public defense of a thesis. The theses are defended via video conferencing through Microsoft Teams between Svishtov and Vinnytsia. For the purposes of their holding, two composition of state examination commissions is determined. Each graduate has two supervisors - respectively from the Bulgarian and Ukrainian side. The developed diploma theses is build on the study in the curriculum of the master's program and include research in the field of: "Financial aspects of forming the development strategy of enterprise“, "Credit policy of a bank with foreign capital“, „Management of credit risks of the consumer lending", "Financial stimulation of the development of small and medium enterprises on the level of city“, "Improvement of the financial performance management of the industrial enterprise (for VOFPP)", "Mechanism for assessing credit risk of business entities engaged in foreign economic activity"; "Insurance of financial flexibility of small business under the capital access constraints"; "Financial risk management in the non-financial corporate sector under divergence of economic cycles in Ukraine and the world"; "Mechanism of trade financial development in foreign business entities"; "Valuation and ensuring the reliability of insurance companies with foreign capital in the financial market of Ukraine", etc. All graduates prepare presentations on their master's theses and answer questions posed in their
\end{abstract}


reviews. The review is by the Ukrainian department, as the representatives of the Bulgarian partner participate in the stage of public defense, ask questions and agree on the final assessments. The training of the first class of Ukrainian students in 2018 is conducted in person, and for the second semester Ukrainian students carry out mobility from Vinnytsia, Ukraine to Svishtov, Bulgaria. In the context of the Covid-19 pandemic, the training of the second class of Ukrainian students in the spring of 2020 is conducted through a system of distance learning and distance taking exams at the D. A. Tsenov Academy of Economics, Svishtov, Bulgaria (dl.uni-svishtov.bg). Thus, students are trained to acquire 30 ECTS credits by participating in lectures, preparing semester assignments and taking an exam in a Moodle environment. Completion of the study process through successful graduation is the basis for the issuance by the two partner universities of academic transcripts certifying the periods of study and the achieved exam results. Following the exchange of these documents, committees of lecturers and administrators apply the regulations of the Erasmus + program in the part of student mobility for educational purposes. On this basis, the Ministries of Education and Science in Sofia and Kiev electronically submit information on each Ukrainian student trained for a double degree, reflecting the subjects taken and the respective grades. On the Bulgarian side, the Ministry of Education and Science issued a hologram sticker confirming the successful graduation of Ukrainian students. The Bulgarian diplomas are signed by the Rector of the D. A. Tsenov Academy of Economics, Svishtov, Bulgaria and the Dean of the Faculty of Finance, and the state seal is affixed to them. After their official signing, the diplomas are sent to a teacher with mobility under the Erasmus + program at Vasyl Stus Donetsk National University, Vinnytsia, Ukraine. Graduates put their handwritten signatures on the title page under a duly updated photo, and the diploma formed with all the necessary details is scanned and digitized for electronic storage on a server of D.A. Tsenov Academy of Economics, Svishtov, Bulgaria and the Ministry of Education and Science at the Council of Ministers of the Republic of Bulgaria. The main conclusion of the scientific report, which presents the step-by-step the know-how, the organization and the conduction of a double degree study process between EU and non-EU countries, is that due to ECTS and Erasmus + program all significant obstacles to such project for international educational partnership projects can be overcome. Under the constraints of the Covid-19 pandemic, the learning process can once again be provided on the basis of university E-learning and distance learning platforms and video conference channels such as BBB, Microsoft Teams or Zoom.

Keywords: Double Diploma Curricula, Master's Degree in Social Science, International Financial Management

\section{INTRODUCTION}

The educational cooperation is an area of social development that builds bridges, crosses borders and creates added value for participating institutions, teachers and students. In order to arrange such cooperation, a comparable regulatory framework, financial support and, above all, motivation for the creation of international educational products is needed. (Zahariev, Simeonov, \& Zaharieva, 2021c). It is thanks to similar circumstances related to the Erasmus + program and ECTS that in 2016 the preparation of the first Bulgarian-Ukrainian joint master's program began. After one year of preparation and discussion the Bulgarian-Ukrainian master's degree program for double degree between D. A. Tsenov Academy of Economics, Svishtov, Bulgaria and Vasyl Stus Donetsk National University, Vinnytsia, Ukraine was approved in 2017. In the academic year 2017/2018 the first alumni of Ukrainian students was accepted, and in the academic year 2019/2020, respectively the second class of Ukrainian students was admitted. The purpose of this report is to present the development of the project, its regulatory framework, achievements and prospects.

\section{THE DOUBLE DIPLOMA MASTER DEGREE PROGRAMME OF INTERNATIONAL FINANCIAL MANAGEMENT}

\subsection{The Regulatory Framework for Double Diploma and Accreditation of Partnering Institutions}

The date of foundation of the D. A. Tsenov Academy of Economics (TAE) is November 8, 1936. The TAE and its Bachelor, Master and Doctoral programmes are accredited by the Bulgarian National Evaluation and Accreditation Agency (NEAA). The national agency is a full member of the European Quality Assurance Register for Higher Education (EQAR) and European Association for Quality Assurance in Higher Education (ENQA). The ISO standards for quality management has been introduced in TAE by the Lloyd's Register of 
Quality Assurance. The TAE has been awarded with Erasmus Charter for Higher Education (ECHE). The award is under the Erasmus+ programme. The accreditation reference of TAE is BG SVISHTO02 with code of the European Erasmus Charta 223613-IC-1-2007-1-BG-ERASMUS-EUCX-1.

The date of foundation of the Vasyl'Stus Donetsk National University (DonNU) is July 15, 1937. Vasyl' Stus DonNU is a member of the European Association of Universities, Eurasian Association of Universities, AIMOS, GUIDE, International University Consortium. The University is also a participant in international programs under the Erasmus +, Sixth and Seventh Framework Programmes of the EU. In 2004, the Vasyl Stus Donetsk National University was the first Ukrainian University who signed the Magna Charta Universitatum and joined the Bologna Process.

The history of the partnership between both universities is full of achievements. The cooperation agreement between the Vasyl' Stus Donetsk National University and the Tsenov Academy of Economics was signed in 1998. For a period of 24 years, the two universities have participated in academic exchanges in Bulgaria and Ukraine. For 17 years, until the events in the Donetsk region in 2014, groups of 10-15 students participated in Summer Schools held in Ukraine and Bulgaria. Since 2016, teachers and students have been participating in international academic mobility under the ERASMUS + program. During this period, 15 joint international scientific-practical conferences on economic cooperation between the Black Sea countries were held, which are rotated annually by a new country - a member of the Organization of the Black Sea Economic Cooperation (http://www.bsec-organization.org/). From upper conferences joint collections of proceedings have been published, joint author's scientific collectives have been formed. Thus in 2017, the collaboration reaches a new dimension with the joint MSc programme of International Financial Management for a double diploma, which already has a double-digit number of graduates in two graduation classes.

The beginning of the discussion of the double degree program was set in Svishtov, Bulgaria during a visit by a delegation of professors from DonNU.After one year of negotiations both institutions signed in Vinnitsya, Ukraine on $26^{\text {th }}$ of May 2017 in the time of official celebrations of $80^{\text {th }}$ anniversary of Vasyl Stus DonNU the agreement on a double diploma programme of International Financial Management for obtaining MSc in the field of Economics with subject Finance.

The Preamble of the Agreement on a double diploma programme on International financial management contains following statement: "In the spirit of prolific international relations and academic cooperation, D. A. Tsenov Academy of Economics (hereinafter referred to as "TAE") and the Vasyl' Stus Donetsk National University (hereinafter referred to as "Vasyl Stus DonNU") wish to strengthen their ties further, in accordance with their mutual interests in delivering programmes of academic excellence and cultural diversity. Hence, Vasyl' Stus DonNU and TAE have decided to conclude this Agreement on a Double Diploma Programme (hereinafter the "DDP") that allows students to obtain Master's degree diplomas, one from each university. This Agreement has been entered into between TAE and Vasyl Stus DonNU to facilitate credit transfer and provide a smooth transition of students from Vasyl Stus DonNU to TAE in order for them to obtain TAE Master's degree in Finance and Vasyl' Stus DonNU Master's degree in Finance, Banking and Insurance. The Agreement is in compliance with both, the Law on Higher Education of Bulgaria and the Law on Higher Education of Ukraine." As a result, the agreement is signed and approved with clear definition of the scope of cooperation, programme management, admission requirements, selection and study programme, structure of the study programme, final thesis, financial issues, and duration, amendment, review and termination of agreement. According the fiscal status of Bulgaria (Zahariev, Radulova, Aleksandrova, \& Petrova, 2021a) the access to the programme for Ukrainian students is organised on a subsidised level with a scholarship for each full-time student by academic foundation "Prof. D-r Minko Roussenov".

\subsection{The Erasmus Experience as a Background for International Educational Partnership - the Evidence from D. A. Tsenov Academy of Economics}

The Erasmus program experience of both partner institutions is crucial for the success of such projects for international educational cooperation. As part of the international activities of TAE at the beginning of the second decade of the 21st century, the achieved know-how and good practice with the intensive program under the Erasmus sectoral program entitled "Management and administration of global public goods" was evaluated as a very useful from the institutional point of view. TAE partners in the implementation of the program were The President Stanislaw Wojciechowski Higher Vocational State School in Kalisz, Poland (PL KALISZ01) and Kaunas University of Technology (KUT), Lithuania (LT KAUNAS02). The summary of the project clearly establishes a framework of international educational partnership focused on a join product provided by three universities from three different EU countries. 
International cooperation in any field of human activity is related to communication, exchange of information and ideas, mutual acquaintance. This requires initiative and desire. The proposal for an intensive program is a step of several institutions towards their further internationalization and integration into the single European higher education area (EHEA). In view of the main objectives of the Erasmus sectoral program, the contribution of the intensive program can be sought in terms of increasing the mobility of students and teachers in Europe; laying the groundwork for new multilateral projects and cooperation based on equality, mutual recognition of achievements and openness to new partners; as well as in supporting the development of innovative, ICT-based learning content and educational approaches.

A workshop was chosen as a form of education of the project. This form has the advantage of briefly concentrating learners' attention on multilateral aspects of the management and administration of global public goods delivery. In this way, knowledge from different parts of economic knowledge is combined. The training under the program aims to contribute to the formation of a new vision in relation to a specific issue the management and administration of the provision of global public goods. The chosen topic for an intensive program is related to the application of a multidisciplinary approach. In itself, it covers a range of common issues that can be considered both from an economic and institutional point of view, and from the point of view of the implemented policies in national and international aspect. As it follows, the Erasmus intensive GPG programme aims to: increasing the volume of student and staff mobility in Europe; improve the quality and increase the volume of multilateral partnerships among students and staff from the partner universities; increase the intensity of utilizations of ICT in the educational process; provide students with structured knowledge in the field of global public goods, the opportunities and mechanisms of their financing and institutional support.

The programme targets senior students pursuing Bachelor degrees in Poland, Lithuania, and Bulgaria, who will be provided the opportunity to study in a multicultural foreign language environment. The programme events were attended by 30 students from the three partner universities. Their training conducted through lectures, presentations and workshops. Training was provided by a team of 10 lecturers.
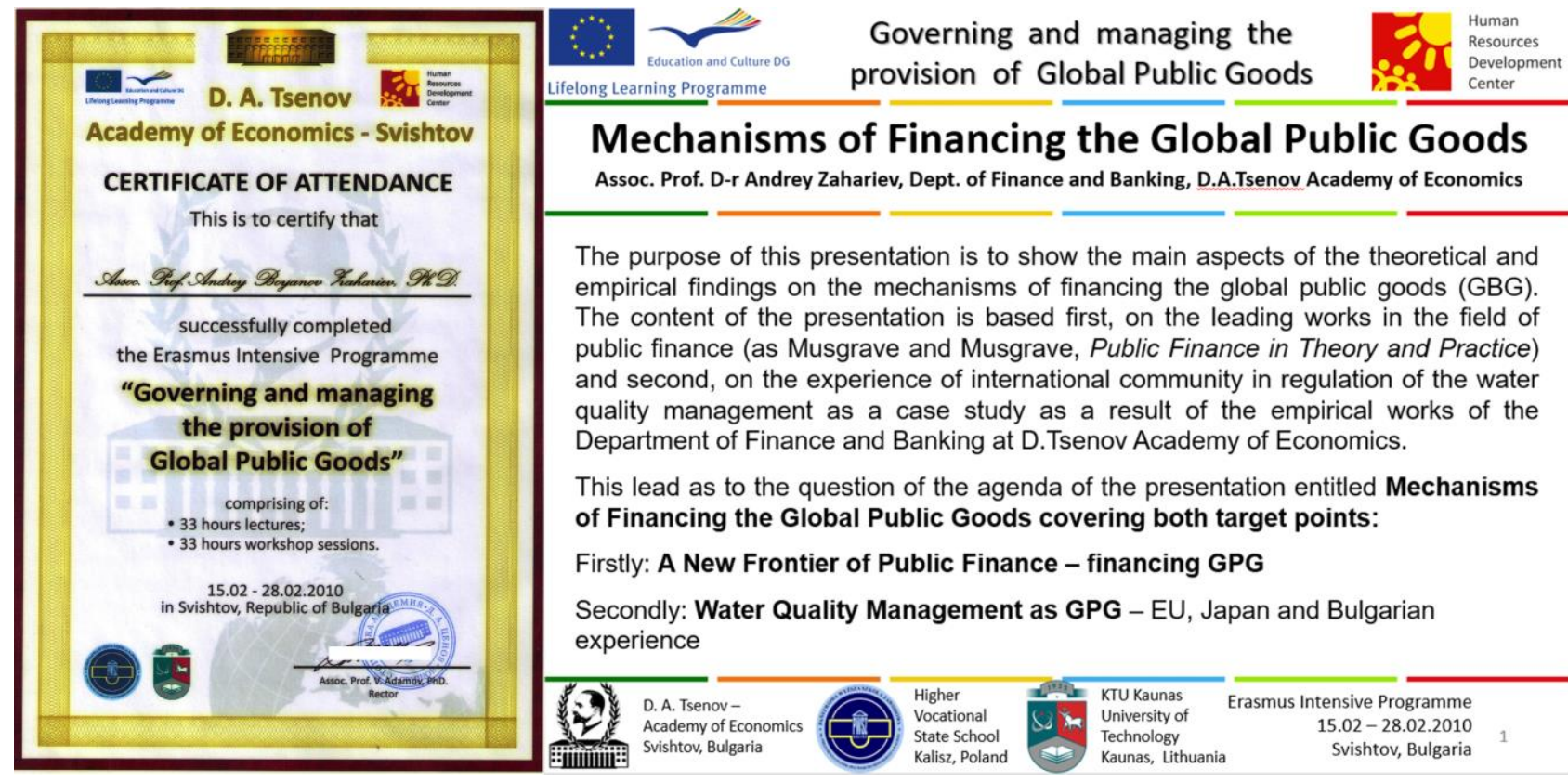

\section{Mechanisms of Financing the Global Public Goods}

Assoc. Prof. D-r Andrey Zahariev, Dept. of Finance and Banking, D.A.Tsenov Academy of Economics

The purpose of this presentation is to show the main aspects of the theoretical and empirical findings on the mechanisms of financing the global public goods (GBG). The content of the presentation is based first, on the leading works in the field of public finance (as Musgrave and Musgrave, Public Finance in Theory and Practice) and second, on the experience of international community in regulation of the water quality management as a case study as a result of the empirical works of the Department of Finance and Banking at D.Tsenov Academy of Economics.

This lead as to the question of the agenda of the presentation entitled Mechanisms of Financing the Global Public Goods covering both target points:

Firstly: A New Frontier of Public Finance - financing GPG

Secondly: Water Quality Management as GPG - EU, Japan and Bulgarian experience

D. A. Tsenov-
$\begin{aligned} & \text { Academy of Economics } \\ & \text { Svishtov, Bulgaria }\end{aligned}$

Fig. 1. The Erasmus intensive programme at TAE in 2010

The main activities included in the project were delivery of a lecture course on the topics included in the curriculum; a workshop for presentation of individual student research papers; a plenary discussion on the curriculum topics with the participation of lecturers, students and representatives of various businesses.

The outcomes of the programme supported students, teachers and administrative staff in improving communication skills in a multicultural environment; improving knowledge in a specific area; dissemination of various teaching methods and techniques; training of 30 students from the three partner universities, collection of study materials based on the lectures given by the visiting lecturers; collection of student research papers presented during the events.

The cost-benefit analyses of the introduction of such very complicated form of international educational 
cooperation is positive regardless of the financial estimates and the costs of providing the educational product chain (Laktionova, Dobrovolskyi, Karpova, \& Zahariev, 2019). Even the break-even-point approach gives for both partnering institutions a lot of advantages and positive experience with regard to the national rating systems and accreditation procedures. The global influence of ECTS and Erasmus+ for such initiatives is without any doubt.

\subsection{The qualification Characteristics of MSc Double Diploma of International Financial Management}

The Masters Degree Programme in International Financial Management (IFM) within the major of Finance is a leading Masters Degree Programme of the D. A. Tsenov Academy of Economics. It represents the will and bequest of the Benefactor for establishment of a Higher Commercial School in Svishtov to teach "... commercial science, financial science, commercial law, banking, insurance sciences, etc." This is why the major is traditional and compliant with the mission and objectives of the higher school. The curriculum was accredited by the National Evaluation and Accreditation Agency (NEAA Protocol No. 17/08.05.2019) as a program accreditation for all educational product of TAE in the field of professional direction Economics. The decision was based on the report by an expert group of reviewers which allows the organization of training for acquisition of Masters Degree in a Masters Degree Programme in International Financial Management within the major of Finance for obtaining double diploma with Vasyl Stus DonNU. The primary educational objective of the Masters Degree Double Diploma Programme (DDP) in IFM within the major of Finance is to train highly qualified specialists and managers with competitive knowledge and practical skills for all levels of the financial and banking system in Bulgaria, Ukraine and the European Union. Designed in compliance with this primary educational objective, Masters Degree Programme in International Financial Management includes theoretical and practical training in the field of corporate finance and investment.

Student training is provided for by the programme documentation which is consistent with the best contemporary academic practices and allows student academic mobility by means of the European Credit Transfer System (ECTS). The curriculum and the syllabus are convergent with those of universities from the European Union member states. It complies with the financial, banking, fiscal and commercial legislation. Students are trained in a full-time with option for access to distance learning platform of studies in English (Zahariev, Mihaylova, Monev, \& Dikov, 2021b). The curriculum includes distance and e-learning modules and activities. The Masters Degree DDP provides the necessary knowledge in the field of corporate finance management, options and derivatives strategies, capital budgeting, human resource management, corporate budget management, international financial management, debt management, foreign exchange markets and transactions, investments, asset transactions, etc.

The training in the Masters Degree DDP in IFM within the major of Finance is provided by the Department of Finance and Credit, which is the first specialized department (established on 8 Apr. 1952) in the field of finance in Bulgaria. For decades it was the only establishment in the country providing higher education graduates for the needs of the financial and banking system. The department employs $15 \%$ of the habilitated lecturers of D. A. Tsenov Academy of Economics. Training is provided by highly qualified faculty of professors and associate professors, doctors in Economics and assistant professors. The faculty have published their own textbooks and study aids covering all training courses taught by the Department within the major of Finance. These teaching aids are constantly updated and complemented with research papers, studies, doctoral and habilitation theses of the Department of Finance and Banking.

The graduates in the Masters Degree DDP in IFM within the major of Finance develop successful careers with investment mediators, financial and brokerage companies, financial and banking institutions, small- and medium-sized enterprises, large corporations, financial departments of institutional investors (insurance companies, pension, health insurance and social security funds), the Ministry of Finance, the customs, tax authorities, auditing authorities, regional and municipal administrations, etc. The graduates have developed successful careers as corporate finance managers, foreign exchange dealers, brokers, investment bankers, loan officers, customs agents, investment brokers, financial analysts, experts in various ministries, regional and municipal administrations, chief financial officers, etc. The duration of study period for acquisition of the educational and qualification degree of Master (in Economics) in full-time form of studies (in English) is 1.5 academic year ( 3 semesters). Graduates acquire the educational and qualification degree of Master and the professional qualification of Economist.

\subsection{The Curricula of MSc Double Diploma of International Financial Management}

The curriculum includes three semesters of full-time study, of which the first and third are provided by the Ukrainian partner and the second semester - by the Bulgarian side. Each semester includes compulsory or 
elective courses, which lead to the accumulation of 30 ECTS credits. The training is in the field of social sciences, professional field "Economics", specialty "Finance" in the master's program "International Financial Management". Teaching and learning documentation is in English only. On the Bulgarian side, all training courses are provided with textbooks prepared by members of the Department of Finance and Banking, which are available in electronic and paper format. Each Ukrainian student is provided with a free set of textbooks by the Bulgarian partner. The first two semesters of the training are in academic disciplines, ending with an exam.
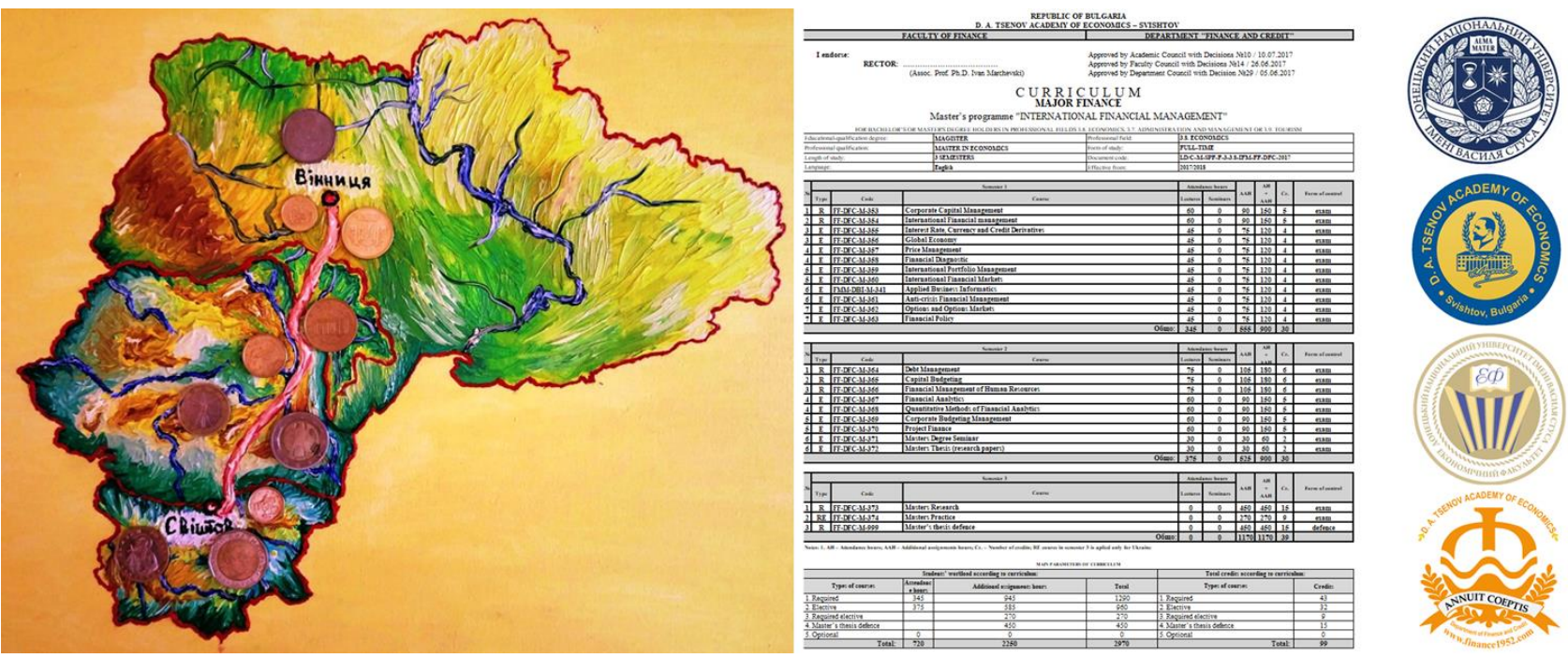

Fig. 2. The Curricula of DDP of IFM with 90 credits according ECTS

ANEX 1

TO THE AGREEMENT ON A DOUBLE DIPLOMA PROGRAMME ON INTERNATIONAL FINANCIAL MANAGEMENT between

D. A. Tsenov Academy of Economics (Srishtor, Bulgaria), represented by Associated Professor Ivan Marchevski, Rector (2 Em Claakarov Str. 5250 Svishtov) and named shortly TAE,

Vasyl' Stus Donetsk National University (Vinnytsia, Ukraine), represented by Professor Grynyul Roman, Rector
(21021, 600-richchya 21, Vinnytsia, Ukraine) and named shortly Vasyl' Stus DonNU

Courses followed at Vasyl Stus DonNU and TAE

All courses amounting to least 60 ECTS credits from two selected specialization areas must be pursued. The remaining courses required to reach the total of 90 ECTS credits shall be selected at TAE. Each ECTS credut is equal to 30 hours student work

Courses in the field of International Financial Management at Vasyl' Stus DonNU and TAE are enlisted in the following tables:

FIRST SEMIESTER: Vinnitsa (15 weeks)

A.1) Compulsory courses with the same name provided from Vinnitsa and Svishtov

\begin{tabular}{|c|c|c|c|c|c|}
\hline$\#$ & Srishtor & Vinnitsa & $\mathrm{Cr}$ & Lectures & Total \\
\hline 1.1. & Corporate Capital Management & 5 & 60 & 150 \\
\hline 1.2. & Intemational Financial management & 5 & 60 & 150 \\
\hline & Total A.1. & 10 & 120 & 300 \\
\hline
\end{tabular}

A.2) Compulsory elective courses provided by Vinnitsa or from Svishtov:

A.2) Compulsory elective courses provided by Vinnitsa or from Svishtov:
\begin{tabular}{|c|l|l|c|c|c|}
\hline$\#$ & \multicolumn{1}{|c|}{ Svishtor } & \multicolumn{1}{|c|}{ Vinnitsa } & $\mathrm{Cr}_{\mathbf{r}}$ & Lectures & Total \\
\hline 1.3. & $\begin{array}{l}\text { Interest Rate, Currency and } \\
\text { Credit Derivatives }\end{array}$ & Global Economy & 4 & 45 & 120 \\
\hline 1.4. & Price Management & Financial Diagnostic & 4 & 45 & 120 \\
\hline 1.5. & $\begin{array}{l}\text { Intermational Portfolio } \\
\text { Management }\end{array}$ & $\begin{array}{l}\text { International financial } \\
\text { markets }\end{array}$ & 4 & 45 & 120 \\
\hline 1.6. & $\begin{array}{l}\text { Applied Business } \\
\text { Informatics }\end{array}$ & $\begin{array}{l}\text { Anti-crisis financial } \\
\text { management }\end{array}$ & 4 & 45 & 120 \\
\hline 1.7. & Options and Options Markets & Financial Policy & 4 & 45 & 120 \\
\hline & Total A.2 & $\mathbf{2 0}$ & $\mathbf{2 2 5}$ & 600 \\
\hline
\end{tabular}

\begin{tabular}{|c|c|c|c|c|c|}
\hline$\#$ & \multicolumn{1}{|c|}{ Srishtor } & Vimnitsa & Cr & Lectures & Total \\
\hline A.1 & \multicolumn{2}{|c|}{ Compulsory } & 10 & 120 & 300 \\
\hline A.2 & $\begin{array}{l}\text { Compulsory elective } \\
\text { provided by Svishtov }\end{array}$ & $\begin{array}{l}\text { Compulsory elective } \\
\text { provided by Vinnitsa }\end{array}$ & 20 & 225 & 600 \\
\hline & Total A.1. + A.2. & 30 & 345 & 900 \\
\hline
\end{tabular}

SECOND SEMESTER: Srishtor (15 weeks)

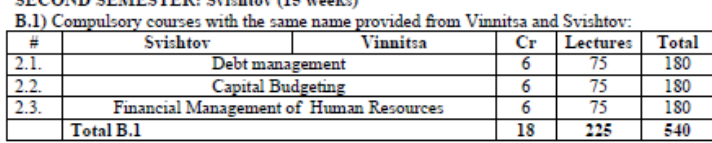

B.2) Compulsory elective courses provided by Vinnitsa or from Svishtov:

\begin{tabular}{|c|l|l|c|c|c|}
\hline$\#$ & \multicolumn{1}{|c|}{ Srishtor } & \multicolumn{1}{c|}{ Vinnitsa } & Cr & Lectures & Total \\
\hline 2.4. & Financial Analytics & $\begin{array}{l}\text { Quantitative Methods of } \\
\text { Financial Analytics }\end{array}$ & 5 & 60 & 150 \\
\hline 2.5 & $\begin{array}{l}\text { Corporate Budgeting } \\
\text { Management }\end{array}$ & Project Finance & 5 & 60 & 150 \\
\hline 2.6 & $\begin{array}{l}\text { Masters Degree } \\
\text { Seminar }\end{array}$ & $\begin{array}{l}\text { Masters Thesis } \\
\text { (research papers) }\end{array}$ & 2 & 30 & 60 \\
\hline & \multicolumn{2}{|l}{ Total B.2 } & 12 & 150 & 360 \\
\hline
\end{tabular}

\begin{tabular}{|c|c|c|c|c|c|}
\hline$\#$ & Srishtor & Vinnitsa & $\mathrm{Cr}_{\mathrm{r}}$ & Lectures & Total \\
\hline B.1 & \multicolumn{2}{|c|}{ Compulsory } & 18 & 225 & 540 \\
\hline B. 2 & $\begin{array}{l}\text { Compulsory elective } \\
\text { provided by Svishtov }\end{array}$ & $\begin{array}{l}\text { Compuleory elective } \\
\text { provided by Vinnitsa }\end{array}$ & 12 & 150 & 360 \\
\hline & \multicolumn{2}{|l|}{ Total B.1. + B.2. } & 30 & 375 & 900 \\
\hline
\end{tabular}

THIRD SEMESTER: Vinnitsa (15 weeks)

C) Compulsory courses provided from Vinnitsa and accepted in Svishto

\begin{tabular}{|l|l|c|c|c|}
\hline & \multicolumn{1}{|c|}{} & $\mathrm{Cr}$ & Lectures & Total \\
\hline 3. & Diploma Defence (incl Masters Research\&Practice) & & & \\
\hline 3.1. & Masters Research & 15 & 0 & 450 \\
\hline 3.2. & Masters Practice & 9 & 0 & 270 \\
\hline 3.3. & Diploma Defence & 6 & 0 & 180 \\
\hline & Total C. & 30 & 0 & 900 \\
\hline
\end{tabular}

NOTE 1. After the completion of both Vasyl' Stus DonNU and TAE programmes, students must have earned no less than 90 ECTS credits.

NOTE 2. According Bulgarian legislation Diploma Defence is 15 ECTS credits and will diploma issued to Ukrainian students for third semester will be with following two positions: \begin{tabular}{|l|l|c|c|c|}
\hline 3. & Diploma Defence and Masters Research & $\mathrm{Cr}$ & Lectures & Total \\
\hline 3.1. & Masters Research & 15 & 0 & 450 \\
\hline 3.2. & Diploma Defence & 15 & 0 & 450 \\
\hline
\end{tabular}

Total C.

NOTE 3. Each cource will be prepared with a Sillabus and will be approved in both institutions according the internal regulations and national legislation.

NOTE 4 . The results from exams of the students will be accepted into the partnerin institution, based on the official Academic reference with the examination results and ECTS credits, signed by the Rector and the Dean.

Fig. 2. The distribution of courses among TAE and Vasyl Stus DonNU within 3 semesters 
According to the curriculum, in the first semester, held in Vinnytsia, Ukraine, training and exams are held in "Corporate Capital Management", "International Financial Management", "Global Economy", "Financial Diagnostics", "International Financial Markets", "Anti-Crisis Policy" and "Financial Policy" (with a total workload of 345 hours of lectures). In the second semester, the study in Svishtov, Bulgaria is in six courses: "Debt Management" (Zahariev, et al., 2020a), "Capital Budgeting" (Prodanov, 2012), "Financial Management of Human Resources" (Zahariev, Financial Management of Human Resources, 2012), "Financial Analytics", "Corporate Budgeting Management" and "Masters Degree Seminar" (total hours of 375 hours of lectures).

\subsection{The first and Second Classes of MSc IFM Double Diploma and the Covid-19 Challenge}

The training of the first class of Ukrainian students in 2018 was organized as a full time study period with mobility from Vinnytsia, Ukraine to Svishtov, Bulgaria. In the context of the Covid-19 pandemic (Zahariev A. , 2021d), the training of the second class of Ukrainian students in the spring of 2020 - in medias of the first wave of Covid-19 - was conducted through a system of distance learning and distance taking of exams at the D. A. Tsenov Academy of Economics, Svishtov, Bulgaria (dl.uni-svishtov.bg). Thus, students acquire 30 ECTS credits by participating in lectures, preparing semester assignments and taking the exams in a Moodle environment.

\subsection{Public Defense of Master Theses, Graduation Procedure and Msc Diploma Issue}

In the third semester there is an undergraduate internship, scientific guidance and review of the thesis. The end of the training is a public defense of a thesis. The theses are defended via video conferencing through Microsoft Teams between Svishtov and Vinnytsia. For the purposes of their holding, two composition of state examination commissions is determined. Each graduate has two supervisors - respectively from the Bulgarian and Ukrainian side. The developed diploma theses is build on the study in the curriculum of the master's program and include research in the field of: "Financial aspects of forming the development strategy of enterprise", "Credit policy of a bank with foreign capital", "Management of credit risks of the consumer lending", "Financial stimulation of the development of small and medium enterprises on the level of city", "Improvement of the financial performance management of the industrial enterprise (for VOFPP)", "Mechanism for assessing credit risk of business entities engaged in foreign economic activity"; "Insurance of financial flexibility of small business under the capital access constraints"; "Financial risk management in the non-financial corporate sector under divergence of economic cycles in Ukraine and the world"; "Mechanism of trade financial development in foreign business entities"; "Valuation and ensuring the reliability of insurance companies with foreign capital in the financial market of Ukraine", etc. All graduates prepare presentations on their master's theses and answer questions posed in their reviews. The review is by the Ukrainian department, as the representatives of the Bulgarian partner participate in the stage of public defense, ask questions and agree on the final assessments.

Completion of the study process through successful graduation is the basis for the issuance by the two partner universities of academic transcripts certifying the periods of study and the achieved exam results. Following the exchange of these documents, committees of lecturers and administrators apply the regulations of the Erasmus + program in the part of student mobility for educational purposes. On this basis, the both Ministries of Education and Science in Sofia and Kiev electronically submit information on each Ukrainian student trained for a double degree, reflecting the subjects taken and the respective grades. On the Bulgarian side, the Ministry of Education and Science issued a hologram sticker confirming the successful graduation of Ukrainian students. The Bulgarian diplomas are signed by the Rector of the D. A. Tsenov Academy of Economics, Svishtov, Bulgaria and the Dean of the Faculty of Finance, and the state seal is affixed to them. After their official signing, the diplomas are delivered via a lecturer with a mobility under the Erasmus + program to Vasyl' Stus Donetsk National University, Vinnytsia, Ukraine. Graduates put their handwritten signatures on the title page under a duly updated photo, and the diploma formed with all the necessary details is scanned and digitized for electronic storage on a server of D.A. Tsenov Academy of Economics, Svishtov, Bulgaria and the Ministry of Education and Science at the Council of Ministers of the Republic of Bulgaria.

\section{CONCLUSION}

The main conclusion of the scientific report, which presents the step-by-step the know-how, the organization and the conduction of a double degree study process between EU and non-EU countries, is that due to ECTS and Erasmus+ program all significant obstacles to such project for international educational partnership projects can be overcome. Under the constraints of the Covid-19 pandemic (Ivanovic-Djukic, Zahariev, \& Lepojevic, 2021e), the learning process can once again be provided on the basis of university E- 
learning and distance learning platforms and video conference channels such as BBB, Microsoft Teams, Skype or Zoom.

\section{ACKNOWLEDGEMENT}

This research was financially supported by the Academic Foundation "Prof. Dr. Minko Roussenov", Svishtov, Bulgaria (Grant No. 1002202) and the Institute of Scientific Research at D. A. Tsenov Academy of Economics, Svishtov, Bulgaria.

\section{REFERENCE LIST}

Ivanovic-Djukic, M., Zahariev, A., \& Lepojevic, V. (2021e). Corporate social responsibility in Covid-19 environment: evidence from Serbia and Bulgaria. Proceedings of the International Scientific Conference: Emerging trends in global and national economy, (pp. 239-250). Faculty of Economics, University of Nish.

Laktionova, O., Dobrovolskyi, O., Karpova, T. S., \& Zahariev, A. (2019). Cost Efficiency of Applying Trade Finance for Agricultural Supply Chains. Management Theory and Studies for Rural Business and Infrastructure Development, 41(1), 62-73. doi:https://doi.org/10.15544/mts.2019.06

Prodanov, S. (2012). Capital Budgeting. V. Tarnovo: ABAGAR.

Terziev, V. (2020b). New strategy for higher education for 2021-2030 in Bulgaria and challenges for its implementation. 60th International Scientific Conference on Economic and Social Development - XX International Social Congress (ISC 2020), 60, pp. 67-75. Moscow. Retrieved from https://www.researchgate.net/publication/345437242

Zahariev, A. (2012). Financial Management of Human Resources. V. Tarnovo: ABAGAR. doi:10.13140/RG.2.1.3561.6402

Zahariev, A. (2021d). Corporate social responsibility under Covid-19 circumstancies: Bulgarian business attitude. Economics and Organization of Management, 3(43), 6-13. doi:https://doi.org/10.31558/2307-2318.2021.3.1

Zahariev, A., Mihaylova, M., Monev, V., \& Dikov, V. (2021b). Upgrading competencies of master's degree students through E-learning in business communications in a foreign language. Abstracts \& Proceedings of SOCIOINT 2021 - 8th International Conference on Education and Education of Social Sciences, 14-15 June 2021 (pp. 25-33). Istanbul: OCERINT. doi:https://doi.org/10.46529/socioint.202103

Zahariev, A., Radulova, A., Aleksandrova, A., \& Petrova, M. (2021a). Fiscal sustainability and fiscal risk in the EU: forecasts and challenges in terms of COVID-19. Entrepreneurship and Sustainability Issues, 8(3), 618-632. doi:https://doi.org/10.9770/jesi.2021.8.3(39)

Zahariev, A., Simeonov, S., \& Zaharieva, G. (2021c). Management motivation and capital creation through employee stock options - International evidences under covid-19 circumstances. Conference Proceedings/Full Paper of 22nd RSEP International Economics, Finance \& Business Conference Virtual/Online 25-26 August 2021 (pp. 113-120). Istanbul, Turkey: Kadir Has University. Retrieved from www.researchgate.net/publication/354238497

Zahariev, A., Zveryakov, M., Prodanov, S., Zaharieva, G., Angelov, P., Zarkova, S., \& Petrova, M. (2020a). Debt management evaluation through support vector machines: on the example of Italy and Greece. Entrepreneurship and sustainability issues, 7. doi:https://doi.org/10.9770/jesi.2020.7.3(61) 